\title{
The ultrastructure changes of Haemonchus contortus exposed to bamboo leaves (Gigantochloa apus) aqueous extract under in vitro condition
}

\author{
BUDI PURWO WIDIARSO ${ }^{1, \boldsymbol{v}}$, WISNU NURCAHYO ${ }^{2}$, KURNIASIH $^{2}$, JOKO PRASTOWO ${ }^{2}$ \\ ${ }^{1}$ Politeknik Pembangunan Pertanian Yogyakarta Magelang. Jl. Magelang-Kopeng Km 7, Magelang 50774, Central Java, Indonesia. \\ Tel.: +62-293-364188, `email: budipw2000@yahoo.com \\ ${ }^{2}$ Faculty of Veterinary Medicine, Universitas Gadjah Mada. Jl. Fauna No. 2, Sleman 55281, Yogyakarta, Indonesia
}

Manuscript received: 7 October 2020. Revision accepted: 5 December 2020.

\begin{abstract}
Widiarso, Nurcahyo W, Kurniasih, Prastowo J. 2021. The ultrastructure changes of Haemonchus contortus exposed to bamboo leaves (Gigantochloa apus) aqueous extract under in vitro condition. Biodiversitas 22: 1-5. The ultrastructural changes induced in adult Haemonchus contortus in vitro using the aqueous extract of bamboo leaves were assessed using scanning electron microscopy (SEM). The H. contortus adult females were obtained from three groups and treatment was repeated thrice. The first group (T0) was not treated with bamboo leaves; $100 \%$ of the worms lived. The second group (T1), treated with $0.1 \%$ bamboo leaf-extract, had $50 \%$ mortality $4 \mathrm{~h}$ after examination. The third group (T2), treated with $1 \%$ bamboo leaf-extract, had $100 \%$ mortality $4 \mathrm{~h}$ after examination. Five worms used per treatment were submerged in ethanol and incubated for 24 hours. The ultrastructural changes observed by SEM revealed structural alteration of the worm surface after in vitro contact with the bamboo leaf aqueous extract and compared to the control worms. The main changes concerned the anterior end or cephalic region, cuticle surface, and vulva flap area. The structural modification of the external part of the female reproductive system was found only in vitro. The structural changes found in the worms exposed to the bamboo leaves might affect their motility and nutrition with possible consequences on their reproduction. Transmission electron microscopy may help to understand the external changes observed in H. contortus.
\end{abstract}

Keywords: Bamboo leaves, extract Haemonchus contortus, in vitro, scanning electron microscopy, ultrastructure

\section{INTRODUCTION}

Bamboo is a plant species of grasses with cavities and segments. Worldwide, bamboo is one of the fastestgrowing plants. This plant has a unique rhizome-dependent system: in a day, bamboo can grow more than $60 \mathrm{~cm}(24$ inches) depending on the soil conditions and climate area (Suratiningsih et al. 2013). From total of 1250 bamboo species in the world, $11 \%$ are found in Indonesia. Among the various kinds, the most used type of bamboo is Petung or Betung, as their leaves have antibacterial activities for livestock, particularly ruminants. (Dendrocalamus asper) (Sujarwo et al. 2010). Bamboo leaves as fodder has been researched and tested by various parties. Bamboo leaves (Dendrocalamus strictus) $100 \mathrm{mg}$ in weight contain: crude protein $15.09 \mathrm{wt} \%$; crude fiber, $23.15 \mathrm{wt} \%$; crude fat 1.43 wt \%; ash 18.03 wt\%; phosphorus 170; calcium, $1550 \mathrm{mg}$ (Widiarso et al., 2018). Bamboo leaves also contain tannins and antibacterial agents. Suratiningsih et al. (2013) reported that a decrease in the concentration of total volatile fatty acids (VFA), in addition to the presence of tannins, also affected the antibacterial properties of bamboo leaves. As a result, they inhibit the growth of bacteria used to help digest food, especially carbohydrates. It was reported that a complete meal without an ethanol extract of bamboo leaves has the greatest effect because it has the highest concentration of total VFA compared to the other parts.
Phytochemical analysis indicates flavonoids and steroid/triterpenoid are present in dried bamboo shoots. An ethanol-water extract of fresh bamboo shoots unveiled flavonoids, phenolic acids, and other phenolic compounds. The flavonoid identified was 4,3',4'-trihydrox yauronol 6-Oglucosides. The phenolic acids identified were $p$ hydroxybenzoic vanillic acid; the glycoside form of $p$ hydroxybenzoic acid and vanillic-syringic acid; and $p$ hydroxybenzoate and vanillates. Additionally, the presence of $p$-hydroxybenzaldehyde was possible. The $n$-hexane extract of dried bamboo shoots enabled isolation of steroids and triterpenoids, allegedly stigmasterol (Zhong et al. 2014).

Another study showed that bamboo leaves contain other active substances, including tannins, flavonoids, polysaccharides, chlorophyll, amino acids, vitamins, and microelements. These materials play an important role: in mitigating oxidation or free radical-formation, in anti-aging ingredients, maintaining stamina, and preventing cardiovascular disease (Widiarso et al. 2018). Over the decades, the use of anthelmintics (a drug class with antihelminthic properties) for the treatment of various gastrointestinal nematode infections in cattle has resulted in drug resistance. In addition to the considerable cost of elucidating new types of anthelmintic derivates, the safety of the food products for the animal is a concern (Buttle et al. 2011) 
For decades, several species of plants that have the ability to prevent gastrointestinal nematode contamination have been utilized. Some researchers have used extracts from papayas, pineapples, figs, and kiwis to substitute for natural anthelmintic. According to Nasai et al. (2016), cysteine proteinases have anti-nematode potential. Buttle et al. (2011) identified a compound that could increase the rupture of intestinal nematode in rats through a new mechanism. The compound was targeted to work on the cuticle by interfering with an internal hydrostatic pressure increase that led to tearing of the worm (Alemu et al. 2014). Kamaraj and Rahuman (2010) suggested tannins, saponins, flavonoids, and alkaloids as anthelmintic surrogates. A 5\% tannin extract from plants could reduce larval contamination and could also be used as anthelmintics.

Bamboo leaves containing condensed tannins have antihelminthic potential against gastrointestinal (GI) worms. Effects of condensed tannins against parasites are through direct interaction with non-condensed nematodes: they affect hatching and growth of the infected larvae (Zaman et al. 2012).

They can also act indirectly by binding plant protein in the rumen. This prevents degradation of the microbe and increases the flow of protein to the duodenum; thereby, increasing host immunity (Eguale et al. 2011). This substance can also bind the protein and the rumen wall, so nematodes become inactive (Qamar and Maqbool 2012).

Tannins in a number of plant species help control internal parasites in animals, for example, Trichostrongylus colubriformis (Mengist et al. 2014). Therefore, the objective of this study was to compare structural changes induced in the adult Haemonchus contortus by contact with different concentrations of bamboo leaf extract in vitro.

\section{MATERIALS AND METHODS}

\section{Parasites collection}

The adult worms used in these in vitro trials were collected from naturally infected goats. The goats were slaughtered in local slaughterhouses in Besi Sleman to collect the abomasa, which were immediately transferred to the Parasitology Laboratory, University of Gadjah Mada (UGM), Yogyakarta, Indonesia.

\section{In vitro exposure to bamboo leaf aqueous extract}

Parasites were collected from the abomasum and submerged into $0.62 \% \mathrm{NaCl}(\mathrm{aq})$. Further, parasites were designated into three groups. All group experiments were repeated thrice. The first group (T0) was not treated with bamboo leaf aqueous extract. The second group (T1) was treated with $0.1 \%$ bamboo leaf aqueous extract and taken 4 $\mathrm{h}$ after adult worm mortality. The third group (T2) was treated with $1 \%$ bamboo leaf aqueous extract and taken $4 \mathrm{~h}$ after adult worm mortality. Five worms were used per treatment submerged in ethanol and were incubated for 24 h. After the incubation period, the worms were collected and were placed in $1.5 \mathrm{ml}$ Eppendorf tubes with fixative for scanning electron microscopy (SEM).

\section{Procedure for scanning electron microscopy (SEM)}

The worms obtained from the in vitro assay were prefixed in a $2.5 \%$ glutaraldehyde solution of $0.1 \mathrm{M}$ sodium cacodylate buffer for $2 \mathrm{~h}$ at $4^{\circ} \mathrm{C}$. These prefixed worms were submerged in $2 \%$ tannic acid for $6 \mathrm{~h}$. After two washes of respectively $15 \mathrm{~min}$ in the same buffer $(0.2$ M) for 4 times and distilled water for 1 time, the worms were dehydrated in a graded ethanol series, dried by critical point drying with EMsCOPE CPD 750 and coated with gold-palladium for $5 \mathrm{~min}$ at $100 \mathrm{~A} \cdot \mathrm{min}^{-1}$. Worms were then observed with a JEOL JSM 5310 LV scanning electron microscope at an accelerating voltage of $15 \mathrm{kV}$ (Goldstein et al. 1992).

\section{RESULTS AND DISCUSSION}

\section{Mortality rate of worms}

Bamboo (Gigantochloaa apus) leaf infusion in vitro can kill $H$. contortus adult worms after a $4 \mathrm{~h}$ immersion. These data are presented in table 1 . The highest worm mortality in the treatment groups both at $2 \mathrm{~h}$ and $4 \mathrm{~h}$ examinations were at the $1 \%$ dose. The lowest worm mortality was in the $0.1 \%$ dose.

The results of the variance analysis conclude that time and dose had significant effects on mortality rates of $H$. contortus in vitro. A dose of $1 \%$ is capable of killing the total number of $H$. contortus adult worms, while a dose of $0.1 \%$ has no ability to kill the parasites.

Figure 1 shows the changes found in $H$. contortus after in vitro exposure to bamboo leaf aqueous extract. The main changes between the control (T0), $0.1 \%$ bamboo leaf aqueous extract (T1)-, and 1\% bamboo leaf aqueous extract (T2)-treated $H$. contortus were observed on the surface anterior end or cephalic region, the surface of the body (cuticle), and the vulva flap of the female worms. These changes were in stark contrast to the control worm body parts, which presented a smooth cuticle surface (T0, T1, and T2). The parasites treated with bamboo leaf aqueous extract lost their normal aspects by showing longitudinal and transversal folds and thicker ridges in the cuticles of $\mathrm{T} 1$. The cuticles of $\mathrm{T} 2$ showed lesions and surface damage.

Table 1. Efficacy of Gigantochloaa apus leaf infusion on mortality rate of adult worms after $2-4 \mathrm{~h}$ immersion

\begin{tabular}{lll}
\hline \multicolumn{1}{c}{ Treatment } & \multicolumn{1}{c}{ 2 hours $(\%)$} & 4 hours $(\%)$ \\
\hline distilled $\mathrm{H}_{2} \mathrm{O} /$ negative control & $0 \pm 0.00^{\mathrm{a}, \mathrm{f}}$ & $0 \pm 00^{\mathrm{a}, \mathrm{f}}$ \\
$0.1 \%$ & $0 \pm 0.07^{\mathrm{a}, \mathrm{f}}$ & $23.33 \pm 5.77^{\mathrm{a}, \mathrm{g}}$ \\
$0.2 \%$ & $20 \pm 0.00^{\mathrm{a}, \mathrm{f}}$ & $30 \pm 0.00^{\mathrm{b}, \mathrm{f}}$ \\
$0.4 \%$ & $30 \pm 0.00^{\mathrm{b}, \mathrm{f}}$ & $53.33 \pm 5.77^{\mathrm{c}, \mathrm{g}}$ \\
$0.6 \%$ & $53.33 \pm 5.77^{\mathrm{c}, \mathrm{f}}$ & $63.33 \pm 5.77^{\mathrm{c}, \mathrm{g}}$ \\
$0.8 \%$ & $70 \pm 10.00^{\mathrm{d}, \mathrm{f}}$ & $80 \pm 0.00^{\mathrm{d}, \mathrm{g}}$ \\
$1 \%$ & $96.67 \pm 5.77^{\mathrm{e}, \mathrm{f}}$ & $100 \pm 0.00^{\mathrm{d}, \mathrm{f}}$ \\
Albendazole/positive control & $73.33 \pm 5.77^{\mathrm{d}, \mathrm{f}}$ & $100 \pm 0.00^{\mathrm{d}, \mathrm{g}}$ \\
\hline
\end{tabular}

Note: Superscripts ${ }^{\mathrm{a}, \mathrm{b}, \mathrm{c}, \mathrm{d}, \mathrm{e}}$ in one column denote a significant difference between treatments. Superscripts ${ }^{\text {f,g }}$ in one line indicate a significant difference between treatments 
In Figure 1, the cephalic region or anterior end of $\mathrm{T} 0$ presented a smooth surface and normal transversal folds. In $\mathrm{T} 1$ and $\mathrm{T} 2$, the transversal folds were lost.

In Figure 2, the $\mathrm{T} 1$ group showed irregular annulus transversal. T2 also reported irregular transversal folds and lesions compared to control (T0) or normal $H$. contortus. Further, a smoother vulva flap is exhibited in T1. The cuticle of T0 was normal. The cuticle of T1 had irregular annulus transversal. In T2, there were irregular transversal folds and cuticular lesions. Sambodo et al. (2018) reported SEM changes in their in vitro studies that revealed interactions between Biophytum petersianum and the cuticle. The presence of wrinkles in the cuticle of $H$. contortus adult worm was also revealed by Yoshihara et al. (2015). The structural cuticular changes described in this study point toward inhibition in the motility of the parasite and disturbance of the nematode's diet, which might eventually lead to worm undernourishment.

Figure 3 showed the vulva flap of T0 was normal and wrinkly. The T1 vulva flab was smoother than in control. The T2 of vulva flap was the smoothest and all wrinkles had disappeared all wrinkles.

The effects of the consumption of fodder from the tannin source on worm population have been investigated for 15 years (Qamar and Maqbool 2012). The effect of feeding nutraceuticals to small ruminants with either a tropical (tzalam), subtropical (sericea lespedeza), or temperate tannin-containing legume (sainfoin) was established in adult $H$. contortus populations. It has also been examined in sheep (Martinez-Ortiz-de Montellano et al. 2010).

The main changes in $H$. contortus adult worms observed between the control, the sainfolin extract, and the tzalam extract concerned the surface of the body, the cephalic region, the vulva, and the anus of the female worms. The parasites treated lost their normal aspect by showing longitudinal and transversal folds as well as thicker ridges in the cuticle. The lesions were observed all over the body or in patches along the nematode body, including the cephalic region. The most striking changes observed were the aggregates located around the buccal capsule, the female vulva, and the anus (Martinez-Ortiz-deMontenallo et al. 2013).

A tannin-rich diet causes a significant reduction in egg excretion that reached $80 \%$ of the control values in some studies (Manolaaraki et al. 2010). This change has been related to either a reduction in worm number (Kuchai et al. 2012) or a reduction in fertility by the female worms (Qamar and Maqbool 2012). Only a few in vitro studies have examined the possible effects of tannin-rich plant extracts on the worm's (including $H$. contortus) functions, such as motility, and mortality in vitro. However, contact with sainfolin extracts has been associated with reduced viability of adult $H$. contortus. (Kuchai et al. 2012).

Some evidence of cuticle lesions has been provided by SEM in nematodes exposed to papaya latex and ficin (plant proteinases) (Yoshihara et al. 2015). However, the current study is the first one that has used SEM to explore structural changes in adult worms induced by bamboo leaves. We do note that some cuticular changes have been observed previously in $T$. colubriformis exposed to chestnut extract - also rich in tannins (Jaiswal et al. 2014)

Bamboo leaves have a tannin content of $8.81 \mathrm{w} / \mathrm{w} \%$ based on total tannin content test according to the UGM integrated testing laboratory. The high amount of tannins are able to play a significant role in protein binding and inactivating nematode walls (Widiarso et al. 2018). Tannins commonly found in plants (Leguminosae) are condensed tannins (Min et al. 2005). Condensed tannins are effective against gastrointestinal parasites. The effect of condensed tannins against gastrointestinal parasites is direct or indirect.

Directly, tannins act through disruption of nematode hatching and also affect the growth of infected larvae. Condensed tannins also have the ability to bind proteins, and inactivate nematode walls, subsequently killing them.

Indirectly, tannins may bind plant proteins in the rumen to prevent microbial degradation. Furthermore, this increases the flow of proteins into the duodenum. Min et al. (2005) have proven that increased protein consumption will decrease parasite infections by increasing host immunity. Sambodo et al. (2020) also report that condensed tannin concentrations over $55 \mathrm{~g}$ per kg dry feed ingredients will decrease feed intake, decrease digestibility, and suppress average daily weight gain of goats.

The SEM changes observed in the in vitro trial proved the occurrence of strong interactions between bamboo leaf aqueous extract and several worm structural components, especially in the anterior end/cephalic region. There is no transversal line on the anterior end in the $0.1 \%$ dosed (T1) or the $1 \%$ dosed (T2) H. contortus, but in the control, the transversal line was not changed. Furthermore, there is no transversal line in the anterior. The potential presence of aggregates in the cephalic region of $H$. contortus might disturb the mechanical and enzymatic metabolism normally involved in the consumption of blood meals by the worms (Martinez-Ortiz-de-Montenallo et al. 2013). It can be speculated that the loss of transversal annulus around the anterior and/or cephalic region may disturb the nematode's nutrition, eventually leading to worm undernourishment, reduced fertility, or mortality (Martinez-Ortiz-deMontenallo et al. 2013).

The main effects were changes in the cuticle surface. The cuticle surface exposed to the transversal annulus was irregular in the dose $0.1 \%$ (T1) and irregular with lesions in the $1 \%$ dose (T2). The cuticle provides shape to the worms. It is also involved in its motility and exchanges in the parasite environment, including the metabolic exchanges with the local environment in the digestive tract of the host (Yoshihara et al. 2015). Associated functional disturbances and the structural cuticle changes described in the current study might lead to impairments in the free movements of the nematodes (i.e., in the search for food and mating opportunities) 


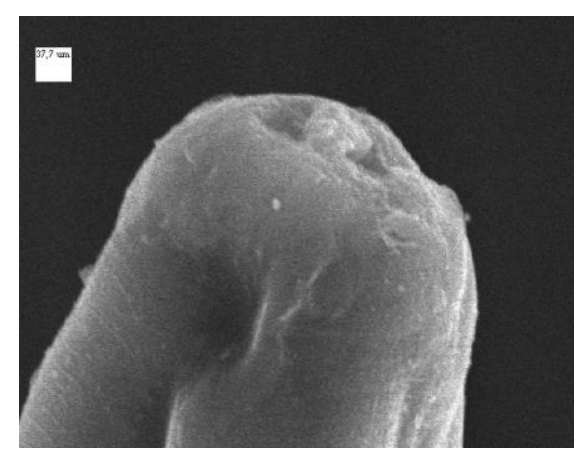

A

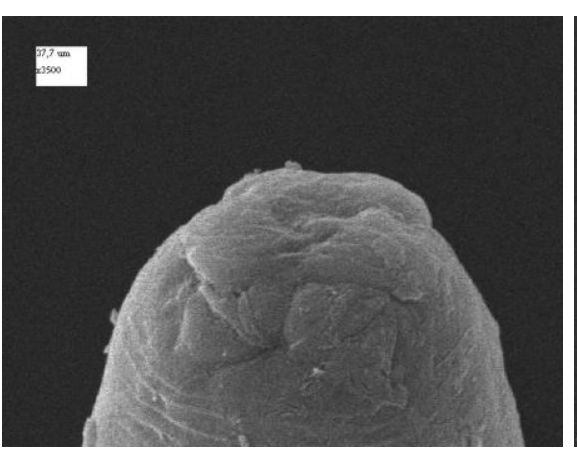

B

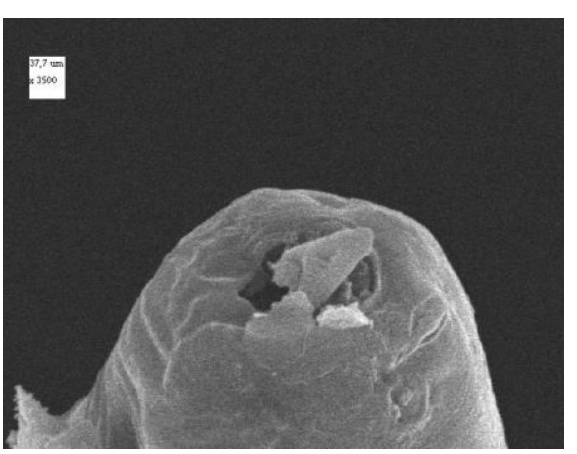

C

Figure 1. SEM of adult female Haemonchus contortus anterior end in contact with. A. $0,62 \% \mathrm{NaCl}(\mathrm{aq})(\mathrm{T} 0)$; B. $0.1 \%$ bamboo leaf aqueous extract (T1); and C. $1 \%$ bamboo leaf aqueous extract (T2) on the anterior end (TYPE JEOL JSM-5000, MAG 3500X , ACCV $20 \mathrm{kV}$, width $264 \mu \mathrm{m})$

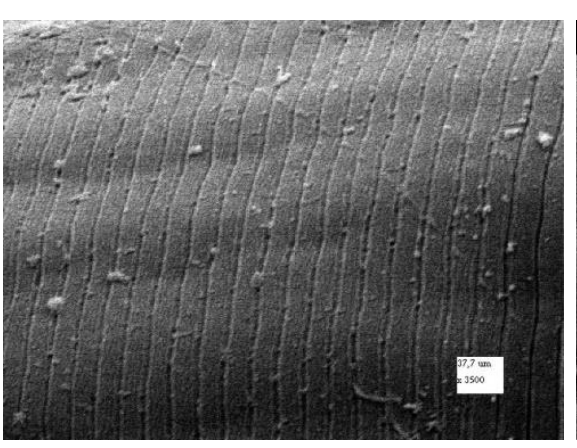

A

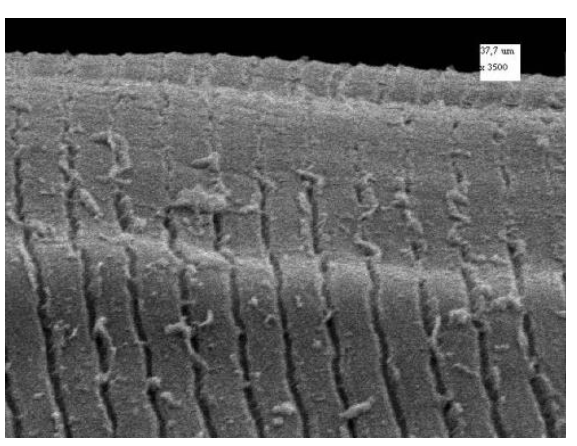

B

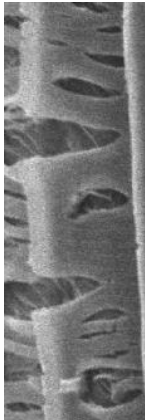

C

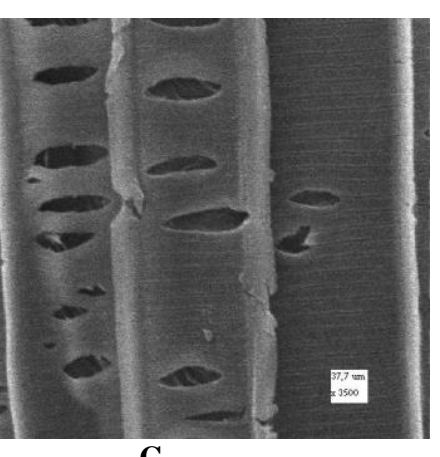

C

Figure 2. SEM of adult female Haemonchus contortus cuticles in contact with: A. 0,62\% $\mathrm{NaCl}(\mathrm{aq})$ (T0); B. $0.1 \%$ bamboo leaf aqueous extract (T1); and C. $1 \%$ bamboo leaf aqueous extract (T2) on the cuticles (TYPE JEOL JSM-5000, MAG 3500 X, ACCV 20kV, width $264 \mu \mathrm{m})$

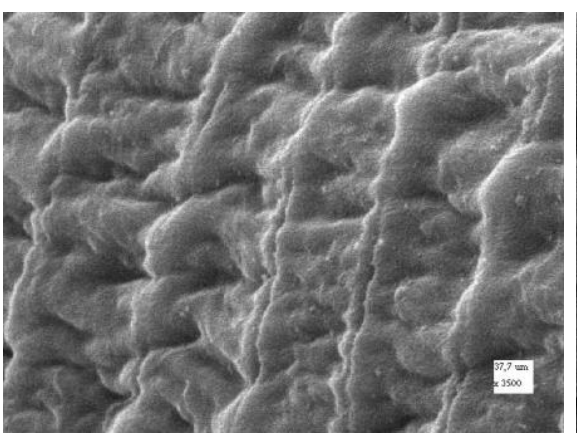

A

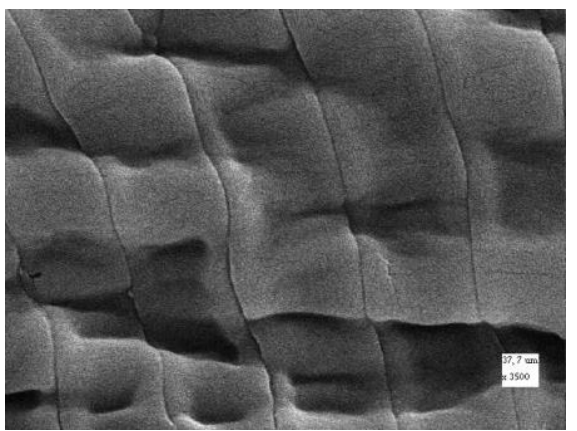

B

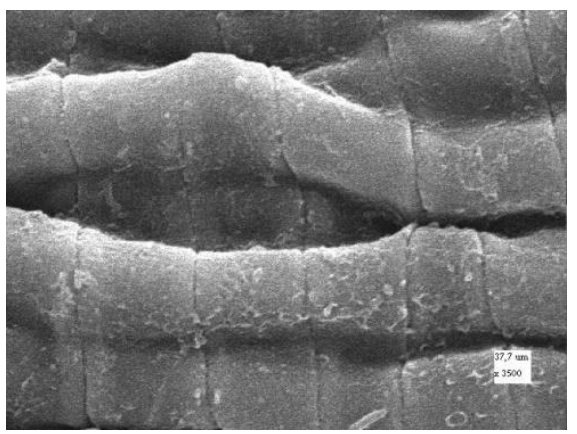

C

Figure 3. SEM of adult female Haemonchus contortus vulva flap in contact with: A. $0,62 \% \mathrm{NaCl}(\mathrm{aq})$ (T0); B. $0.1 \%$ bamboo leaf aqueous extract (T1); and C. $1 \%$ bamboo leaf aqueous extract (T2) on the vulva flap (TYPE JEOL JSM-5000, MAG 3500 X, ACCV $20 \mathrm{kV}$, width $264 \mu \mathrm{m})$

The structural changes in the vulva flap of female worms in vitro showed that the flap surface was smoother in the $0.1 \%$ dose (T1), but in the $1 \%$ dose (T2) the vulva flap surface was smoother and without wrinkles. The structural changes in vulva flap could affect the nematodes reproductive function (e.g. by mechanical obstruction to egg production or expulsion). On the other hand, the direct effect on the reproductive tract has not been confirmed in vivo. However, we hypothesize that reproductive processes, particularly egg production, might also be affected by nutritional disturbances. These observations are consistent with the significant decrease in egg excretion reported when animals consume tannin-rich sources (Daryatmo et al. 2010) resulting in reduced female fertility (Martinez -Ortiz-de-Montenallo et al. 2010). It can also be hypothesized that the high diversity in the nature of the tannins and difference between plants could influence their 
interactions with the worm macromolecules, especially proteins and glycoproteins.

The bamboo leaf aqueous extract has provided significant differences in mortality rates of $H$. contortus in vitro. A dose of $1 \%$ is capable of killing the total number of $H$. contortus adult worms, but a dose of $0.1 \%$ has no ability to kill the parasites.

The ultrastructural changes that could be observed by SEM revealed structure alteration in the worms by in vitro subjugation to bamboo leaf extract aqueous compared to the control worms. The main changes in $H$. contortus concerned the anterior end or cephalic region, cuticle surface, and the vulva flap area. Structural modification to the external parts of the female reproductive systems was found only in vitro.

\section{REFERENCES}

Alemu Z, Kechero Y, Kebede A, Mohammed A. 2014. Comparison of the in vitro inhibitory effects of doses of tannin-rich plant extracts and ivermectin on egg hatchability, larvae development, and adult mortality of Haemonchus contortus. Acta Parasitol Glob 5 (3): 160168.

Buttle DJ, Behnke JM, Bartley Y, Elsheikha HM, Bartley DJ, Garnett MC, Donnan AA, Jackson F, Lowe A, Duc IR. 2011. Oral dosing with papaya latex is an effective anthelmintic treatment for sheep infected with Haemonchus contortus. Parasites Vectors 4 (36): 1-11. DOI: $10.1186 / 1756-3305-4-36$.

Daryatmo J, Hartadi H, Orskov ER, Adiwimarta K, Nurcahyo W. 2010 In vitro screening of various for-ages for anthelmintic activity on Haemonchus contortus eggs. Adv Anim Biosci 1: 113. DOI: $10.1017 / \mathrm{S} 2040470010002566$.

Eguale T, Tadesse D, Giday M. 2011. In vitro anthelmintic activity of crude extract of five medicinal plants against egg hatching and larval development of Haemonchus contortus. J Ethnopharmacol 137 (1): 108-113

Goldstein JI, Newbury DE, Echlin PDC, Joy AD, Romig Jr, Lyman C, Fiori C, Lifshin E. 1992. Scanning Electron Microscopy and X-Ray Microanalysis: A Text for Biologist, Materials Scientist, And Cytologists. 2nd ed. Plenum Press, New York.

Jaiswal AK, Sudan V, Pandey V, Singh A, Gaur RS, Kanojiya D, Nigam R, Shaanker D. 2014. Sex-dependent alterations in the protein characterization pat-terns of Haemonchus contortus. J Parasit Dis 40 (3): 1006-1016.

Kamaraj C, Rahuman A. 2010. Larvicidal and adulticidal potential of medicinal plant extract from south India against vectors. Asian Pac J Trop Med 3 (12): 948-953.
Kuchai JA, Ahmad F, Chishti MZ, Tak H, Ahmad JAS, Razool M. 2012. A study on morphology and morphometry of Haemonchus contortus. Pak J Zool 44 (6): 1737-1741

Manolaaraki F, Sotiraki S, Stefanakis A, Skampardonis V, Volanis M, Hoste H. 2010. Anthelmintic activity of some Mediterranean browse plants against parasitic nematodes. Parasitology 137 (4): 684-696

Martinez-Ortiz-de-Montenallo C, Vargaz-Magana AJ, Canul-Ku L, Miranda-Oberanis R, Capetillo-Leal C, Sandoval-Castro CA, Hoste H, Torres-costa JFJ. 2010. Effect of a tropical tannin-rich plant, Lysiloma latisiliquum on adult population of Haemonchus contortus in sheep. Vet Parasitol 172: 283-290.

Martinez-Ortiz-de-Montenallo C, Vargaz-Magana AJ, Canul-Ku L, Miranda-oberanis R, Capetillo-Leal C, Sandoval-Castro CA, Torrescosta JFJ, Hoste H. 2013. Scanning electron microscopy of Haemonchus contortus exposed to tannin-rich plants under in vivo and in vitro conditions. Exp Parasitol 133: 281-286.

Mengist Z, Abebe N, Gugsa G, Kumar N. 2014. Assessment of small ruminant Haemonchosis and its associated risk factors in and around Finoteselam, Ethiopia. IOSR-JAVS 7 (12): 36-41.

Min BR, Hart SP, Miller D, Tomita, GM, Loetz E, Sahlu T. 2005. The effect of grazing forage containing condensed tannins on gastrointestinal parasite infection and milk composition in Angora does. Vet Parasitol 130 (1-2): 105-113.

Nasai NB, Abba Y, Abdullah FFJ, Marimuthu M, Tijjani A, Sadiq MA, Mohammed K, Chung ELT, Omar MAB. 2016. In vitro larvicidal effects of ethanolic extract of Curcuma longa Linn. on Haemonchus larval stage. Vet World 9 (4): 417-420.

Qamar MF, Maqbool A. 2012. Biochemical studies and serodiagnosis of Haemonchosis in sheep and goats. J Anim Plant Sci 22 (1): 32-38.

Sambodo P, Prastowo J, Kurniasih K, Indarjulianto S. 2018. In vitro potential anthelmintic activity of Biophytum petersianum on Haemonchus contortus. Vet World 11 (1): 1-4. DOI: 10.14202/vetworld.2018.1-4

Sambodo P, Prastowo J. Kurniasih K, Mubarokah WM, Sudarmanto I. 2020. In vivo efficacy of Biophytum petersianum on Haemonchus contortus in goats. Adv Anim Vet Sci 8 (3): 238-244.

Sujarwo W, Arinasa IBK, Peneng IN. 2010. Inventory types of bamboo potential as drug in Karangasem Bali. Bot Gard Bull 13 (1): 28-33.

Suratiningsih, Rahayu S, Suhartati FM. 2013. Supplementation ethanol extract bamboo leaves petung (Dendrocalamus asper) effect on concentration of $\mathrm{N}^{-\mathrm{NH}_{3}}$ and VFA total in vitro. Jurnal Ilmiah Peternakan 1 (2): 590-596. [Indonesian]

Widiarso BP, Kurniasih K, Prastowo J, Nurcahyo W. 2018. Morphology and morphometry of Haemonchus contortus exposed to Gigantochloa apus crude aqueous extract. Vet World 11 (7): 921-925.

Yoshihara E, Minho AP, Tabacow VBD, Cardim ST, Yamamura MH 2015. Ultrastructural changes in the Haemonchus contortus cuticle exposed to Acacia mearnsii extract. Ciências Agrárias Londrina 36 (6): 3763-3768

Zaman MA, Iqbal Z, Khan MN, Muhammad G. 2012 Anthelmintic activity of a herbal formulation against gastrointestinal nematodes of sheep. Pak Vet J 32 (1): 117-121.

Zhong RZ, Sun HX, Liu HW, Zhou DW. 2014. Effects of tannic acid on Haemonchus contortus larvae viability and immune responses of sheep white blood cells in vitro. Parasite Immunol 36: 100-106. 